\title{
Changes in bread making quality of wheat during postharvest maturations
}

\author{
Anna Szafrańska@*; Sylwia M. Stępniewska 미 \\ Department of Grain Processing and Bakery, Prof. Wacław Dąbrowski Institute of Agricultural and Food Biotechnology, \\ State Research Institute, Rakowiecka 36, 02-532 Warsaw, Poland
}

Received March 22, 2021; accepted June 11, 2021

\begin{abstract}
The purpose of this study was to determine the changes in bread making quality for three wheat cultivars during their postharvest grain maturation phase. Grain samples were collected immediately after harvest in two consecutive years. Over the next 12 weeks the changes of the technological value of grains were determined. The wheat cultivars were characterized by varying quality in terms of the properties of gluten proteins. Changes to the baking value of grains which occur during their postharvest maturation phase were dependent on the cultivar and harvest year: the amount of wet gluten present decreased slightly in all tested cultivars, whereas the quality of the gluten improved. The greatest changes in the gluten index occurred for cv. Bamberka in both harvest years as a result of its low initial value - below $80 \%$. The greatest improvement in alveograph properties was found for wheat cultivars with a lower baking value which was determined just after harvest. A slight increase in the water absorption of the flour was observed, as well as slight increases in bread yield and bread crumb hardness. Grain processors should expect an improvement in the baking value "W" and dough tenacity "P" of grain after its post-maturation phase in comparison with the quality values determined just after harvest.

Keywords: baking quality, gluten properties, wheat cultivars, wheat maturation
\end{abstract}

\section{INTRODUCTION}

Grain harvested directly from the field demonstrates metabolic changes of a significant intensity that affect both its quality and durability during storage. The postharvest maturing of the wheat begins immediately after harvest, continues during storage, and depends on the time, ambient

*Corresponding author e-mail: anna.szafranska@ibprs.pl conditions of storage and the grain moisture content (Janić Hajnal et al., 2014). The intensity of metabolic changes depends, initially, on the maturity of the grain. During the postharvest maturation phase, a number of biochemical changes occur until a well-defined final state of maturity is reached. The grain moisture content decreases and there are changes in both the quantity and quality of the protein and starch complex as well as in enzymatic activity. As a result, the bread making quality of the grain is improved (Mense and Faubion, 2017). A characteristic feature of the process of maturity of the grain is the dominance of the synthesis process over the decomposition and hydrolysis of chemical compounds in the grain. According to Tomić et al. (2013) the amount of free sulphydryl groups of gluten increased during this period. Under normal storage conditions, the grain maturation process takes anything from approximately 10 to 12 weeks (Tipples, 1995; Sypuła and Dadrzyńska, 2008).

In the case of milling companies, which obtain wheat grain from the same region every year, it is a standard practice to gradually increase the proportion of grain from new harvests in relation to grain from the previous year's harvest, starting from 5 to $10 \%$ (Fowler, 2014). This process allows for a maximum extension of the postharvest maturation of grain until the milling company is obliged to use $100 \%$ of the wheat grain from the new harvest year. This

(C) 2021 Institute of Agrophysics, Polish Academy of Sciences 
process also allows for the adaptation of bakery production technology to changes in the quality of delivered flour obtained from grain originating from new harvests.

In recent years, it has been observed that more and more wheat grain is being processed directly after the grain has been harvested. This creates new challenges in the milling and bakery industry, because flour produced from newly harvested wheat, which has not undergone postharvest maturation, is characterized by a lower milling and baking quality (Wang and Flores, 1999; Dirndorfer, 2012). After several weeks of wheat storage, the bran is easier to separate from the endosperm of the grain, the flour yield increases and the ash content decreases (Dirndorfer, 2012). This feature, however, varied depending on the wheat cultivar tested (Tipples, 1995). Wheat flour obtained from grain after several weeks of postharvest maturation is characterized by a higher degree of water absorption, an improved mixing tolerance and the greater gas retention capabilities of the dough, it also produces bread with a larger loaf volume (Wang and Flores, 1999; Dirndorfer, 2012).

Changes in the commonly used quality parameters of wheat grain indicate that during the postharvest maturation period, changes to the rheological characteristics of a dough should also be expected. However, there is as yet no available literature data to provide an answer to the following question - what level of changes in the rheological properties of dough occur in this period?

The purpose of this study was to determine the changes in the bread making quality of three wheat cultivars (spring and winter forms) during their postharvest grain maturation phase with regard to the protein complex as determined both by the primary quality parameters and the rheological properties of the dough.

\section{MATERIAL AND METHODS}

The study included three wheat cultivars representing two technological groups: Kandela (quality bread cultivar, spring, Danko, Poland), Bamberka (quality bread cultivar, winter, HRS, Poland) and KWS Ozon (bread cultivar, winter, KWS Lochow Polska, Poland).

The wheat grain was cultivated over a period of two seasons: 2014-2016 at the experimental fields of the Mazovian Agricultural Advisory Centre in Płońsk (N 52 $37^{\prime} 24^{\prime \prime}$, E $20^{\circ} 22^{\prime} 31^{\prime \prime}$ ). Winter wheat was sown on October 3rd, 2014 and September 30th, 2015. The crop density was 380 germinable seeds $\mathrm{m}^{-2}$. Spring wheat was sown on March 24th, 2015 and March 31st, 2016. The crop density was 450 germinable seeds $\mathrm{m}^{-2}$. Mineral fertilization (NPK) was applied before the winter wheat was sown, at a concentration equivalent to $20 \mathrm{~kg}$ of N, $50 \mathrm{~kg}$ of $\mathrm{P}_{2} \mathrm{O}_{5}$, and $100 \mathrm{~kg}$ of $\mathrm{K}_{2} \mathrm{O} \mathrm{ha}^{-1}$. An additional dose of $70 \mathrm{~kg}$ of $\mathrm{N} \mathrm{ha}^{-1}$ was applied at the heading stage (BBCH 51) (Witzenberger et al., 1989). Mineral fertilization (NPK) was applied before the wheat was sown at a concentration equivalent to $79 \mathrm{~kg}$ of N, $50 \mathrm{~kg}$ of $\mathrm{P}_{2} \mathrm{O}_{5}$ and $120 \mathrm{~kg}$ of $\mathrm{K}_{2} \mathrm{O} \mathrm{ha}{ }^{-1}$. The grain was harvested at full maturity.
Immediately after grain harvest, approximately $60 \mathrm{~kg}$ of grain from each cultivar was packed in a polypropylene bag and placed in a laboratory room, it was protected from light, with a controlled temperature (in the range of 20 to $24.9^{\circ} \mathrm{C}$ ) and relative humidity (in the range of 45 to $62 \%$ ). The moisture content of the grain was determined using the oven method (ISO 712) and was in the range of 11.1 to 15.6 and of 10.4 to $12.3 \%$, for cultivars harvested in 2015 and 2016, respectively.

Immediately after grain harvest and over the course of the next 12 weeks, at two-week intervals, the following assessment of the baking value was performed: gluten content, gluten index (ISO 21415-2) and Zeleny sedimentation index (ISO 5529). Grain samples, with a mass of $3 \mathrm{~kg}$ each, were adjusted to $16 \%$ moisture content with water. After conditioning overnight for $24 \pm 1 \mathrm{~h}$, the samples were milled in a CD1 laboratory mill (Chopin Technologies, France) in order to obtain flour for the determination of the rheological properties of dough by alveograph (ISO 27971) and mixolab (ISO 17718) (Chopin Technologies, France) and the laboratory baking test. The average flour yield for samples of cv. Bamberka was $62.2 \%$ in 2015 and $59.8 \%$ in the 2016 harvest year, respectively, while for the same two harvest years, for cv. KWS Ozon: 60.1 and 53.6\%, respectively, and finally for cv. Kandela: 66.9 and $63.2 \%$, respectively. The rheological properties of the dough were determined on the second day after milling, and on the third day - the baking test.

A standard baking test for pan bread made with wheat flour (Freund and Kim, 2006) was used to prepare a dough following the one-stage method with the use of a laboratory mixer (KitchenAid, USA). The dough was prepared at $28-30^{\circ} \mathrm{C}$ by mixing flour $(100 \%)$, water (according to the water absorption capacity indicated by Mixolab $+3 \%$ ), yeast (3\%) and salt (1\%). The dough was fermented at $30^{\circ} \mathrm{C}$ and $75 \% \mathrm{RH}$ for $60 \mathrm{~min}$ in a proving cabinet. One rekneading was performend $30 \mathrm{~min}$ after that. The dough was then divided into three parts weighing $250 \mathrm{~g}$ each which were rounded and placed in baking tins in a proving cabinet for the time required for optimal dough development (38$47 \mathrm{~min}$ ). The loaves were baked at $230^{\circ} \mathrm{C}$ for $30 \mathrm{~min}$ in an oven (Piccolo Wachtel Winkler, Germany). After $20 \pm 1 \mathrm{~h}$ of cooling each sample was analysed in terms of specific volume $\left(\mathrm{cm}^{3} 100 \mathrm{~g}^{-1}\right.$ of bread) and bread crumb hardness (Instron 1140, USA).

All tests were performed in duplicate. The results were statistically evaluated using a three-way analysis of variance (ANOVA) with a subsequent Tukey's HSD test at $p<0.01$ and $p<0.05$. The three main factors were: the wheat cultivar used, harvest year and week after harvest. A principal component analysis (PCA) was performed on the whole data set. Statistical analyses were carried out using the Statistica 13 program. 


\section{RESULTS AND DISCUSSION}

Protein content and quality significantly influences the baking value of wheat cultivars and the baking process, by determining the physical properties of the dough such as: water absorption ability, dough stability, dough resistance and elasticity (Codina and Paslaru, 2008; Dhaka et al., 2012; Geisslitz et al., 2019).

The quality parameters characterizing the gluten proteins such as gluten content (GC), gluten index (GI) and Zeleny sedimentation index (ZI) depended on the wheat cultivar used, harvest year and postharvest maturity (Tables 1 and 2). Cv. Bamberka was characterized by the best quality of gluten proteins (the highest GC and ZI), whereas cv. KWS Ozon had the lowest. The differences indicate that the grain of the studied cultivars can be used for various baking purposes. The highest average value of GI was observed for the cv. KWS Ozon (98), which indicates that bread obtained from such flour dough may be characterized by overly strong dough properties (Table 2), whereas cv. Bamberka and Kandela were suitable for the production of bakery products (Bonfil and Posner, 2012).

During postharvest maturation GC and ZI decreased and the quality of gluten (GI) improved (Table 2). These changes are the result of two features: the dry gluten con- tent and water absorption of gluten. With the domination of the synthesis processes over decomposition during grain maturation, the likely cause of the decrease in wet gluten quantity is a decrease in the ability of the gluten to bind water. Similar effects for gluten quantity and quality were found by Linina and Ruza (2015) after 60 days of storage of 2 wheat cultivars and Janić Hajnal et al. (2014), who reported an increase in GI during postharvest wheat maturation after 50 days of storage. Whereas, a decrease in GC and an improvement in the quality of gluten were observed by Sypuła and Dadrzyńska (2008). Kibar (2015) found that ZI and GC increased with the duration of the storage period until the first 2 months and subsequently decreased.

In the current study, the greatest changes in GC between weeks after harvest for both harvest years was observed for cv. Kandela (4 and 3\% lower in the 12th week after harvest compared to harvest day, for 2015 and 2016, respectively) and the lowest value for cv. KWS Ozon (1.3 and 1.0\% lower, respectively in the same period of time). The changes in GI and ZI for cv. Bamberka were greater for the grain from the second harvest year than from the first. The GI values of wheat cv. Bamberka and Kandela just after harvest were 77 and 74, respectively. Two weeks after harvest the quality of gluten improved - GI increased to 84 and 86 , respectively and was stable for the next 8 weeks. Whereas the GI for cv.

Table 1. Analysis of variance of the qualitative parameters for the tested wheat samples and bread obtained in the baking trial (F value)

\begin{tabular}{|c|c|c|c|c|c|c|c|}
\hline \multirow[b]{2}{*}{ Parameter } & \multirow{2}{*}{$\begin{array}{l}\text { Wheat } \\
\text { cultivar } \\
\text { (A) }\end{array}$} & \multirow{2}{*}{$\begin{array}{c}\text { Harvest } \\
\text { year } \\
\text { (B) }\end{array}$} & \multirow{2}{*}{$\begin{array}{l}\text { Week after } \\
\text { harvest } \\
\text { (C) }\end{array}$} & \multicolumn{4}{|c|}{ Interaction } \\
\hline & & & & $\mathrm{AxB}$ & $\mathrm{AxC}$ & $\mathrm{BxC}$ & $\mathrm{AxBxC}$ \\
\hline GC & $4444.34 * *$ & $971.16^{* *}$ & $8.49 * *$ & $58.05^{* *}$ & 2.41 & 1.35 & 2.16 \\
\hline GI & $367.37 * *$ & 6.45 & $15.76^{* *}$ & 5.77 & 7.20 & 0.80 & 2.28 \\
\hline ZI & $3358.99 * *$ & $5110.77 * *$ & $54.69^{*}$ & $184.77 * *$ & 13.09 & 9.45 & 14.82 \\
\hline \multicolumn{8}{|c|}{ Alveograph parameters } \\
\hline $\mathrm{W}$ & $6066.92 * *$ & $940.67 * *$ & $93.04 *$ & $97.12^{*}$ & 31.71 & 11.93 & 18.76 \\
\hline $\mathrm{P}$ & $3057.84 * *$ & 6.52 & $36.92 *$ & $99.61 * *$ & 7.29 & $25.05^{*}$ & 7.37 \\
\hline $\mathrm{L}$ & $6663.55^{* *}$ & 84.16 & 36.83 & $403.24 * *$ & 27.20 & 54.77 & 17.49 \\
\hline \multicolumn{8}{|c|}{ Mixolab parameters } \\
\hline WA & $6030.09 * *$ & $7852.12 * *$ & 12.96 & 122.32 & 6.25 & 9.40 & 5.37 \\
\hline $\mathrm{T} 1$ & $4342.42 * *$ & 43.99 & 38.54 & $409.56^{* *}$ & 18.16 & 15.29 & 14.94 \\
\hline St & $36.30 * *$ & $18.29 * *$ & 0.15 & $6.32 * *$ & 0.53 & 0.79 & 0.88 \\
\hline \multicolumn{8}{|c|}{ Bread qualitative features } \\
\hline Bread yield & $175.06^{* *}$ & $203.03 * *$ & $24.45 * *$ & $11.45^{* *}$ & 2.93 & $6.26^{* *}$ & 1.02 \\
\hline Specific volume & 18.33 & $48.87^{*}$ & 6.83 & 7.45 & 3.42 & 9.14 & 8.05 \\
\hline Crumb hardness & $91.55 * *$ & $26.21 * *$ & 8.43 & 9.98 & 9.70 & $19.41 * *$ & 3.58 \\
\hline
\end{tabular}

GC - gluten content, GI - gluten index and ZI - Zeleny sedimentation index, W - dough baking strength, P-dough tenacity, L- dough extensibility, WA - water absorption, T1 - development time, St - stability time. Significant at: ${ }^{*} \mathrm{p}<0.05, * * \mathrm{p}<0.01$. 
Table 2. Qualitative features of the tested wheat samples

\begin{tabular}{|c|c|c|c|c|c|c|c|c|c|}
\hline \multirow[b]{2}{*}{ Factor } & \multirow[b]{2}{*}{$\begin{array}{l}\text { GC } \\
(\%)\end{array}$} & \multirow[b]{2}{*}{ GI } & \multirow{2}{*}{$\begin{array}{c}\mathrm{ZI} \\
\left(\mathrm{cm}^{3}\right)\end{array}$} & \multicolumn{3}{|c|}{ Alveograph parameters } & \multicolumn{3}{|c|}{ Mixolab parameters } \\
\hline & & & & $\begin{array}{c}\mathrm{W} \\
\left(10^{-4} \mathrm{~J}\right)\end{array}$ & $\begin{array}{c}\mathrm{P} \\
(\mathrm{mm})\end{array}$ & $\begin{array}{c}\mathrm{L} \\
(\mathrm{mm})\end{array}$ & $\begin{array}{l}\text { WA } \\
(\%)\end{array}$ & $\begin{array}{c}\mathrm{T} 1 \\
(\mathrm{~min})\end{array}$ & $\begin{array}{c}\mathrm{St} \\
(\mathrm{min})\end{array}$ \\
\hline Range & $18.6-33.4$ & $72-99$ & $38-70$ & $154-416$ & $49-149$ & $30-167$ & $52.6-63.2$ & $1.1-6.9$ & $8.0-11.0$ \\
\hline \multicolumn{10}{|c|}{ Wheat cultivar } \\
\hline Bamberka & $31.5^{\mathrm{a}}$ & $84^{b}$ & $62^{\mathrm{a}}$ & $385^{\mathrm{a}}$ & $111^{\mathrm{b}}$ & $106^{\mathrm{b}}$ & $60.5^{\mathrm{a}}$ & $5.6^{\mathrm{a}}$ & $10.6^{\mathrm{a}}$ \\
\hline KWS Ozon & $22.4^{\mathrm{c}}$ & $98^{\mathrm{a}}$ & $45^{\mathrm{c}}$ & $218^{\mathrm{b}}$ & $127^{\mathrm{a}}$ & $43^{\mathrm{c}}$ & $59.2^{\mathrm{b}}$ & $1.3^{\mathrm{c}}$ & $9.7^{\mathrm{b}}$ \\
\hline Kandela & $28.5^{\mathrm{b}}$ & $83^{\mathrm{b}}$ & $51^{\mathrm{b}}$ & $248^{\mathrm{b}}$ & $63^{c}$ & $136^{\mathrm{a}}$ & $54.9^{\mathrm{c}}$ & $3.3^{\mathrm{b}}$ & $9.1^{\mathrm{c}}$ \\
\hline \multicolumn{10}{|c|}{ Harvest year } \\
\hline 2015 & $27.6^{\mathrm{a}}$ & $88^{\mathrm{a}}$ & $59^{\mathrm{a}}$ & $263^{\mathrm{b}}$ & 99 & 92 & $60.2^{\mathrm{a}}$ & 3.5 & $9.5^{\mathrm{b}}$ \\
\hline 2016 & $23.9^{b}$ & $89^{\mathrm{a}}$ & $46^{\mathrm{b}}$ & $309^{\mathrm{a}}$ & 101 & 98 & $56.3^{\mathrm{b}}$ & 3.3 & $10.1^{\mathrm{a}}$ \\
\hline \multicolumn{10}{|c|}{ Week after harvest } \\
\hline 0 & $26.8^{\mathrm{a}}$ & $83^{b}$ & $55^{\mathrm{a}^{*}}$ & $264^{\mathrm{b}^{*}}$ & $92^{\mathrm{b}^{*}}$ & 94 & 58.0 & 3.5 & 9.8 \\
\hline 2 & $26.6^{\mathrm{a}}$ & $90^{\mathrm{a}}$ & $54^{\mathrm{ab}^{*}}$ & $294^{\mathrm{ab}^{*}}$ & $98^{\mathrm{ab}^{*}}$ & 103 & 58.2 & 3.1 & 9.9 \\
\hline 4 & $25.8^{\mathrm{ab}}$ & $90^{\mathrm{a}}$ & $52^{\mathrm{ab}^{*}}$ & $278^{a b^{*}}$ & $98^{\mathrm{ab}^{*}}$ & 93 & 58.3 & 3.1 & 9.8 \\
\hline 6 & $25.7^{\mathrm{ab}}$ & $89^{\mathrm{a}}$ & $53^{\mathrm{ab}^{*}}$ & $277^{\mathrm{ab}^{*}}$ & $101^{\mathrm{ab}^{*}}$ & 88 & 58.3 & 3.7 & 9.9 \\
\hline 8 & $25.0^{\mathrm{b}}$ & $89^{\mathrm{a}}$ & $52^{\mathrm{ab}^{*}}$ & $300^{\mathrm{a}^{*}}$ & $107^{\mathrm{a}^{*}}$ & 94 & 58.2 & 3.1 & 9.7 \\
\hline 12 & $24.5^{\mathrm{b}}$ & $89^{\mathrm{a}}$ & $50^{\mathrm{b}^{*}}$ & $304^{\mathrm{a}^{*}}$ & $105^{\mathrm{a}^{*}}$ & 99 & 58.5 & 3.7 & 9.7 \\
\hline
\end{tabular}

The "Range" applies to all years, cultivars and all grain storage times. The results are shown as mean values: different letters in the same column indicate a significant difference $(\mathrm{p}<0.01$ or $* \mathrm{p}<0.05)$ individual in each factor (wheat cultivar, harvest year and week after harvest). Other explanations as in Table 1.

KWS Ozon was stable for all 12 weeks of storage in both years studied. The interaction between the cv. and harvest year significantly affect the GC, and ZI (Table 1).

The baking value " $\mathrm{W}$ " in the tested cultivars ranged from 154 to $416 \times 10^{-4} \mathrm{~J}$ (Table 2) which, according to Bordes et al. (2008), Dapčević Handadev et al. (2011) and Jeantet et al. (2016), indicates their wide technological suitability. The results of cv. Bamberka ("W" over $300 \times 10^{-4} \mathrm{~J}$ ) indicates its potential use for the production of hamburger buns or frozen dough, while cv. KWS Ozon and Kandela $\left(200-300 \times 10^{-4} \mathrm{~J}\right)$ may be used for the production of traditional bread and pastries.

Despite having the lowest average GC of wheat samples from the second harvest year, the baking value "W" was significantly higher than that of the wheat samples from the first year (Table 2) and varied according to the tested cultivars used. The increase in this parameter during the postharvest maturation period was found in $\mathrm{cv}$. KWS Ozon and Kandela (with an average increase of 75 and $44 \times 10^{-4} \mathrm{~J}$, respectively) while the $\mathrm{W}$ value immediately after the grain harvest was below $260 \times 10^{-4} \mathrm{~J}$ (Fig. 1). The $\mathrm{W}$ value of cv. Bamberka decreased slightly during the postharvest maturity period for the first harvest year (from 390 to $366 \times 10^{-4} \mathrm{~J}$ ) and also increased for the second year (from 385 to $410 \times 10^{-4} \mathrm{~J}$ ).

The tenacity "P" of the dough is dependent on the viscosity of dough. The highest "P" value was observed for cv. KWS Ozon $(127 \mathrm{~mm})$ which was also characterized by the highest GI. A slight increase (significant at $\mathrm{p} \leq 0.05$ ) was observed in the "P" value during postharvest maturity. Dough extensibility "L" which may be used to predict the handling properties of the dough (Dapčević
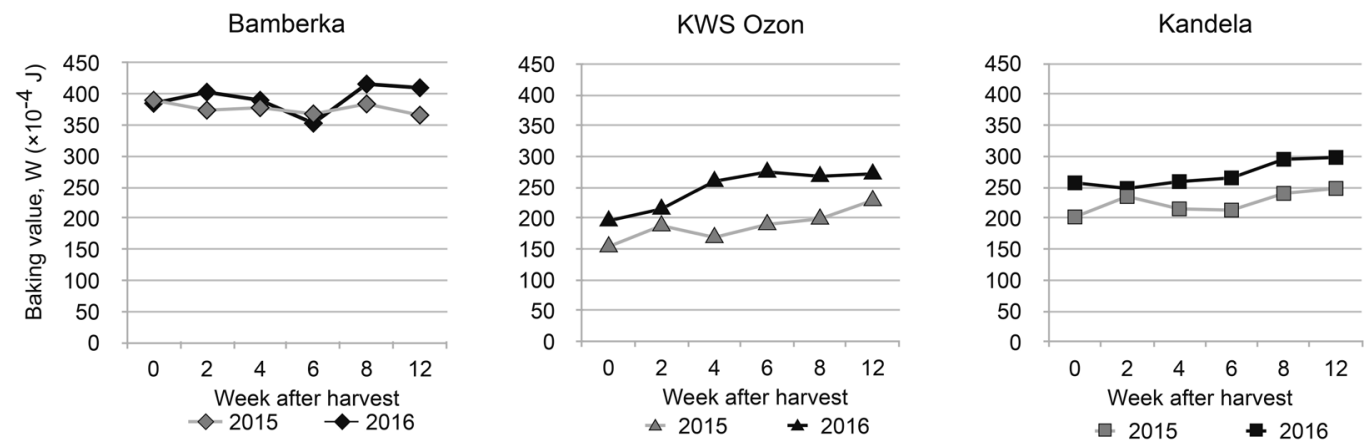

Fig. 1. Changes in the baking value "W" of the tested wheat cultivars: "Bamberka", "KWS Ozon" and "Kandela" during postharvest maturation. 
Hadnadev et al., 2011) in tested wheat samples was in the range of 30-167 $\mathrm{mm}$ (Table 2). The highest extensibility was observed for cv. Kandela $(136 \mathrm{~mm})$ and the lowest for KWS Ozon $(43 \mathrm{~mm})$. The dough obtained from $\mathrm{cv}$. KWS Ozon was characterized by a very high level of tenacity and very low extensibility, which means that it is more difficult to work and the bread is less developed with, a compact bread crumb. This is a characteristic of this cultivar. Interaction between $\mathrm{cv}$. and harvest year affects the dough baking strength "W", tenacity "P" and extensibility "L". Whereas, the interaction between the harvest year and week after harvest only affects "P" (Table 1).

Water absorption (WA), an indicator of baking quality which is related to protein quality, damaged starch and wheat polysaccharides (Okuda et al., 2016) in the tested grain ranged from 52.6 to $63.2 \%$ (Table 2). The highest WA value was observed for cv. Bamberka, whereas the lowest value was determined for cv. Kandela. Statistically significant differences in the WA values of the flour were found between harvest years, on average this amounted to $3.9 \%$. As a result of the postharvest maturation of grain the WA value of the tested flour samples increased slightly, regardless of the wheat cultivar and harvest year. However, in contrast to the results of Posner and Deyoe (1986), Dirndorfer (2012) and Elmann (2011), the postharvest maturation period had no significant influence on the WA value of the flour (Tables 1 and 2). According to Posner and Deyoe (1986) and Dirndorfer (2012), the wheat flour obtained from grain after several weeks of postharvest maturation is character- ized by a higher WA value, an improved mixing tolerance, greater gas retention capabilities of the dough and produces bread with a larger loaf volume than the bread originating from grain just after harvest. Elmann (2011) showed that 6 months of storage under optimum conditions significantly improved the WA value of flours.

The dough development time (T1) and stability during mixing (St), which determined the strength of wheat (Caffe-Treml et al., 2010), were significantly dependent on the choice of cultivar. $\mathrm{Cv}$. Bamberka was characterized by a longer T1 time and stability than other tested wheat cultivars, which indicates its favourable properties (Table 2). However the changes in these parameters during postharvest maturation were not statistically significant.

Bread yield (BY), which is dependent on the WA value, the quantity and quality of gluten proteins and starch damage, was in the range of $133-146 \%$ (Table 3 ) and varied between all of the factors of the experiment. A significantly lower BY characterized the wheat from cv. Kandela (137\%) and samples from the second harvest year (138\%). During the postharvest maturation period a significant increase in BY was observed.

The specific volume of the bread was in the range of $212-313 \mathrm{~cm}^{3}$ (Table 3). The lowest average value was determined for $\mathrm{cv}$. KWS Ozon $\left(251 \mathrm{~cm}^{3}\right)$, which was characterized by the lowest GC and ZI with the highest value of GI and tenacity "P" at the same time. This indicates that the dough obtained from this cultivar may be too strong and may not produce a high volume bread. The bread volume

Table 3. Qualitative features of the tested bread obtained in the baking test

\begin{tabular}{cccc}
\hline & $\begin{array}{c}\text { Bread yield } \\
(\%)\end{array}$ & $\begin{array}{c}\text { Specific volume } \\
\left(\mathrm{cm}^{3} 100 \mathrm{~g}^{-1} \text { of bread }\right)\end{array}$ & $\begin{array}{c}\text { Bread crumb hardness } \\
(\mathrm{N})\end{array}$ \\
\cline { 2 - 4 } Factor & \multicolumn{2}{c}{ Range } \\
\cline { 2 - 4 } & $133-146$ & $212-313$ & $9.8-23.8$ \\
\hline Bamberka & $141^{\mathrm{a}}$ & Wheat cultivar & $19.1^{\mathrm{b}}$ \\
KWS Ozon & $141^{\mathrm{a}}$ & $266^{\mathrm{a}}$ & $24.3^{\mathrm{a}}$ \\
Kandela & $137^{\mathrm{b}}$ & $251^{\mathrm{b}}$ & $23.5^{\mathrm{a}}$ \\
& & $268^{\mathrm{a}}$ & 22.1 \\
2015 & $141^{\mathrm{a}}$ & Harvest year & 22.6 \\
2016 & $138^{\mathrm{b}}$ & $253^{\mathrm{b}^{*}}$ & 21.7 \\
& & $270^{\mathrm{a}^{*}}$ & 21.3 \\
0 & $138^{\mathrm{b}}$ & & 20.8 \\
2 & $138^{\mathrm{b}}$ & 247 & 22.9 \\
4 & $140^{\mathrm{a}}$ & 266 & 22.8 \\
6 & $141^{\mathrm{a}}$ & 266 & 24.4 \\
\hline 12 & $140^{\mathrm{a}}$ & 265 & 268 \\
\hline
\end{tabular}

Explanations as in Table 2. 
increased slightly during the postharvest maturation of the tested wheat samples, whereas in the research of Elmann (2011) the opposite effect was observed. The observed differences were not statistically significant (Tables 1 and 3).

Bread crumb hardness $(\mathrm{BCH})$ varied between the cultivars tested (Table 3 ). The bread obtained from $\mathrm{cv}$. Bamberka was characterized by a favourable $\mathrm{BCH}$, the lowest value of this parameter $(19.1 \mathrm{~N})$. With the extension of the postharvest maturation period, an unfavourable increase in $\mathrm{BCH}$ was observed (from an average value 21.7 to $24.4 \mathrm{~N}$ ), but the differences were not statistically significant. The postharvest maturation period may influence the bread staling process. The greatest differences during the postharvest maturation period of the grain were found for cv. Kandela (from an average value of 15.1 to $21.3 \mathrm{~N}$ ), and the lowest for cv. KWS Ozon (from 16.8 to $17.0 \mathrm{~N}$ ). This means that the bread obtained from cv. Kandela after several weeks from the time of the grain harvest may be characterized by an increased bread crumb hardness and a shorter shelf life. The interaction between the harvest year and the week after harvest affects the bread yield and bread crumb hardness (Table 1).

The results of a principal component analysis revealed that the first two principal components (PC1, PC2) explained $70.28 \%$ of the variation (Fig. 2). The first principal component (PC1) accounted for $39.55 \%$ of the variation and was the most negatively related to GC, ZI, alveograph parameter " $\mathrm{L}$ " and mixolab parameter - T1. PC1 was the most positively related to GI and alveograph tenacity "P". The second principal component (PC2) explained 30.73\% of the variation and was positively related to $\mathrm{BCH}$ to a significant extent and negatively related to WA, BY and alveograph tenacity "P".

Figure 3 shows that the all grain samples of cv. Bamberka and cv. Kandela are grouped in the left part of the graph, while the grain samples of cv. KWS Ozon are grouped in the right part. This finding indicates that grain samples of cv. KWS Ozon were characterized by relatively higher GI and "P" values and lower GC, "L" values and T1 values compared to other tested wheat cultivars. Furthermore, it was revealed that the samples of cv. Bamberka are grouped in the lower left part of the graph, while the grain samples of cv. Kandela are located in the upper left part of the graph. This indicates that the two aforementioned cultivars differ significantly. The grain samples of cv. Bamberka, compared to the samples of cv. Kandela, were characterized by a significantly higher WA value and tenacity "P". Breads obtained from flour from the grain of cv. Bamberka were characterized by a higher yield and lower hardness compared to bread obtained from the grain of cv. Kandela. The impact of the harvest year and week after harvest on the quality parameters of the wheat cultivars of the study were much smaller compared to the effect of the cultivar.

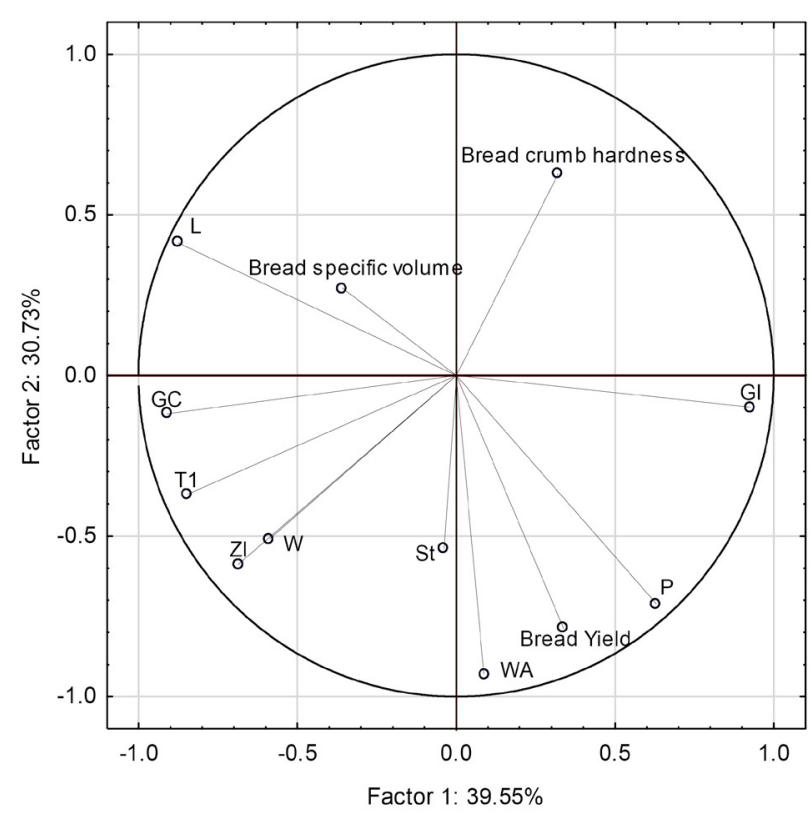

Fig. 2. Principal component analysis (PCA): loading plot of PC1 and $\mathrm{PC} 2$ for the evaluated parameters of the tested wheat samples. For definitions of GC, GI, ZI, WA, T1, St, W, P, L see Table 1.

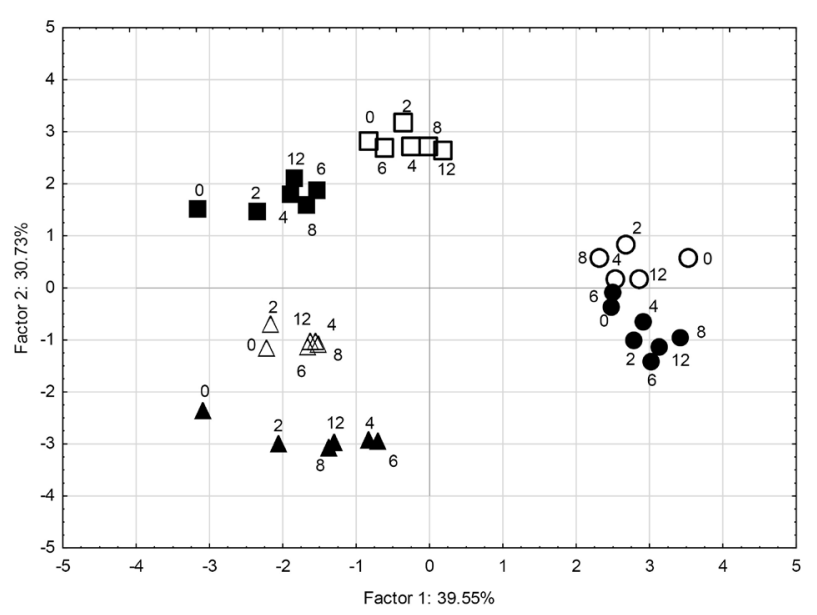

Fig. 3. Principal component analysis: score plot of PC1 and PC2 for the studied wheat cultivars: $\square-$ Kandela, $\bigcirc-$ KWS Ozon, $\Delta-$ Bamberka 2015 year; - Kandela, $\bullet$ - KWS Ozon, $\boldsymbol{\Delta}$ - Bamberka 2016 year; the numbers indicate the week after harvest.

\section{CONCLUSIONS}

1. Changes in the baking value of the tested wheat grain during postharvest maturation were dependant on the wheat cultivar and harvest year. During the twelve week postharvest maturation period the wet gluten content decreased and the quality of the gluten (gluten index, baking value "W") improved. However, the Zeleny sedimentation index decreased.

2. An increase in the alveograph baking value "W" during the postharvest maturation period was observed in wheat cultivars which were characterized by a medium 
baking value immediately after the grain harvest. The baking value "W" of the strong dough wheat cultivar decreased slightly during the postharvest maturity period for the first harvest year and increased slightly for the second.

3 . The changes in water absorption, development time and stability time were not statistically significant. The differences between the values of these parameters which were determined in the weeks after the harvest met the relevant requirements of repeatability specified in the appropriate standard.

4. A significant increase in bread yield and bread crumb hardness obtained from the tested wheat cultivars during their postharvest maturation period was observed, although changes in specific volume were not statistically significant.

5. It was proven that the levels of postharvest maturation changes depended on the wheat cultivar used and its form (spring or winter).

Conflict of interest: The authors declare no conflict of interest.

\section{REFERENCES}

Bonfil D.J. and Posner E.S., 2012. Can bread wheat quality be determined by gluten index? J. Cereal Sci., 56, 115-118. https://doi.org/10.1016/j.jcs.2012.07.003

Bordes J., Brandlard G., Oury F.X., Charmet G., and Balfourier F., 2008. Agronomic characteristics, grain quality and flour rheology of 372 bread wheats in a worldwide core collection. J. Cereal Sci., 48: 569-579. https://doi. org $/ 10.1016 / j . j c s .2008 .05 .005$

Caffe-Treml M., Glover K.D., Krishnan P.G., and Hareland G., 2010. Variability and relationships among Mixolab, mixograph, and baking parameters based on multi- environment Spring Wheat Trials. Cereal Chem., 87, 574-580. https://doi.org/10.1094/cchem-04-10-0068

Codina G.G. and Paslaru V., 2008. Effect of gluten vital on the alveograph characteristics and bread quality of flour wheat dough with a weaker potential for bread making. Revista Lucrări ştiinţifice. Seria Agronomie, 51, 106-111.

Dapčević Hadnađev T., Pojić M., Hadnađev M., and Torbica A., 2011. The role of empirical rheology in flour quality control, wide spectra of quality control. (Ed. I. Akyar), Intech Open. Available at https://www.intechopen.com/ books/wide-spectra-of-quality-control/ the-role-of-empirical-rheology-in-flour-quality-control, https://doi.org/10.5772/24148

Dhaka V., Gulia N., and Khatkar B.S., 2012. Application of Mixolab to assess the bread making quality of wheat. Open Access Scientific Reports, 1, 183.

Dirndorfer M., 2012. Flour quality: flour aging - the effects on flour quality and baking performance. Buhler AG. Available at https://www.buhlergroup.com/global/en/services_technology-centers-test-facilities bakery-innovation-center latest-news details-11173.htm?title

EImann T., 2011. Effect of intensity of agricultural techniques and grain storage on technological quality of winter wheat'. Part II. Quality traits of flour and bread. Acta Scientarum Polonorum, Agricultura, 10, 37-46.
Fowler M., 2014. Adapting for change. New wheat crop brings different challenges, opportunities for flour millers. WorldGrain.com September 2014. Available at https://www. world-grain.com/articles/10209-adapting-for-change (accessed Oct 8, 2020).

Freund W. and Kim M.-Y., 2006. Determining the baking quality of wheat and rye flour. In: Popper L. et al. (eds). Future of flour. Agrimedia GmbH, Germany, 114-115.

Geisslitz S., Longin C.F.H., Scherf K.A., and Koehler P., 2019. Comparative study on gluten protein composition of ancient (Einkorn, Emmer and Spelt) and modern wheat species (Durum and Common wheat). Foods, 8, 409. https://doi. org/10.3390/foods 8090409

Janić Hajnal E., Tomić J., Torbica A., Rakita S., Pojić M., Živančev D., Hadnađev M., and Dapčević Hadnađev T., 2014. Content of free amino groups during postharvest wheat and flour maturation in relation to gluten quality. Food Chem., 164, 158-165. https://doi.org/10.1016/j. foodchem.2014.05.054

Jeantet R., Croguennec T., Schuck P., and Brulé Gérard. (eds), 2016. Handbook of Food Science and Technology 3. Food Biochemistry and Technology. ISTE Ltd., John Wiley and Sons, Inc. https://doi.org/10.1002/9781119296225

Kibar H., 2015. Influence of storage conditions on the quality properties of wheat cultivars. J. Stored Products Res., 62: 8-15. https://doi.org/10.1016/j.jspr.2015.03.001

Linina A. and Ruza A., 2015. Weather conditions effect on fresh and stored winter wheat grain gluten quantity and quality. In: Proc. 25th Congress (NJF) Nordic View to sustainable Rural Development, 16-18 June 2015, Riga, Latvia, 148-153.

Mense A.L. and Faubion J.M., 2017. Effects of aging new crop wheat and flour on breadmaking quality and lipid composition. Cereal Foods World, 62: 4-10. https://doi.org/10.1094/ cfw-62-1-0004

Okuda R., Tabara A., Okusu H., and Seguchi M., 2016. Measurement of water absorption in wheat flour by mixograph test. Food Sci. Technol. Res., 22: 841-846. https://doi. org/10.3136/fstr.22.841

Posner E.S. and Deyoe C.W., 1986. Changes in milling properties of newly harvested hard wheat during storage. Cereal Chem., 63: 451-456.

Sypuła M. and Dadrzyńska A., 2008. Effect of storing time of wheat grain on changes in its quality properties (in Polish). Inżynieria Rolnicza, 1, 371-376.

Tomić J., Pojić M., Torbica A., Rakita S., Živančev D., Janić Hajnal E., Dapčević Hadnađev T., Hadnađev M., 2013. Changes in the content of free sulphydryl groups during postharvest wheat and flour maturation and their influence on technological quality. J. Cereal Sci., 58, 495-501. https:// doi.org/10.1016/j.jcs.2013.09.012

Tipples K.H., 1995. Quality and nutritional changes in stored grain, in: Stored grain ecosystems (Eds D.S. Jayas, N.D.G. White, W.E.) Muir Marcel Dekker Inc.

Wang L. and Flores R.A., 1999. The effect of storage on flour quality and baking performance. Food Reviews Int., 15, 215-234. https://doi.org/10.1080/87559129909541187

Witzenberger A., Hack H., and van den Boom T., 1989. Erläuterungen zum BBCH-Dezimal-Code für die Entwicklungsstadien des Getreides-Mit Abbildungen. Gesunde Pflanzen, 41, 384-388. 